\title{
THE IMPLEMENTATION OF LMS-GOOGLE CLASSROOM TO IMPROVING COMPETENCE SKILL OF SENIOR HIGH SCHOOL TEACHERS' IN INDUSTRIAL REVOLUTION 4.0
}

\author{
Rahmi Ramadhani ${ }^{1)}$, Ermayanti Astuti ${ }^{2)}$, Titin Setiawati ${ }^{3)}$ \\ Universitas Potensi Utama ${ }^{1)}$ \\ Universitas Potensi Utama ${ }^{2)}$ \\ Universitas Potensi Utama ${ }^{3)}$
}

\begin{abstract}
ABSTRAK
Kegiatan program kemitraan masyarakat stimulus (PKMS) yang dilakukan berupa pelatihan implementasi Learning Management System (LMS)-Google Classroom dalam proses pembelajaran untuk meningkatkan kompetensi guru SMA An-Nizam dalam menghadapi era Revolusi Industri 4,0. Jumlah peserta pelatihan ini sebanyak 25 orang guru. Target luaran kegiatan PKMS ini adalah 1) peningkatan pemahaman dan pengetahuan para guru dalam membuat konten bahan ajar, LKS hingga evaluasi penilaian berbasis LMS-Google Classroom dalam proses pembelajaran; 2) peningkatan keterampilan para guru dalam menggunakan LMSGoogle Classroom; dan 3) peningkatan motivasi serta antusiasme para guru dalam menerapkan LMS-Google Classroom. Metode kegiatan PKMS ini dilakukan dalam empat tahapan. Tahap pertama adalah konfirmasi dan observasi pendahuluan pada sekolah mitra. Tahap kedua adalah pelaksanaan pelatihan yang diisi dengan turorial penggunaan LMS-Google Classroom. Tahap ketiga adalah implementasi LMS-Google Classroom yang telah dikembangkan (IN dan ON). Tahap keempat adalah evaluasi hasil implementasi. Hasil yang diperoleh dari kegiatan PKMS ini diantaranya 1) para guru mampu memahami cara membuat dan mengembangkan LMS-Google Classroom baik secara konten bahan ajar hingga alat evaluasi penilaian berbasis digital; 2) para guru mampu menggunakan LMS-Google Classroom yang telah dibuat; dan 3) para guru mampu mengundang siswa untuk bergabung dan mempelajari konten bahan ajar maupun evaluasi penilaian dalam LMS-Google Classroom secara antusias dan semangat.
\end{abstract}

Kata kunci: LMS-Google Classroom, Kompetensi Guru SMA, Revolusi Industri 4,0

\begin{abstract}
This stimulus society partnership program (PKMS) was carried out in the form of a training on implemention of learning management system (LMS)-Google Classroom in learning process to improve teachers' competence in senior high school in the face of Industrial Revolution 4,0. The target of this PKMS activities are 1) to increase teachers understanding and knowledge about how to make learning tool contents, students worksheet (LKS) and evaluation tools based on LMSGoogle Classroom; 2) to improve teachers' skill in using LMS-Google Classroom; and 3) to increase teachers' motivation and enthusiasm to practice LMS-Google Classroom. This method of this PKMS activity is carried out in four stages. The first stage is confirmation and pre-liminary observation in the partner school. The second stage is the phase of the training which filled with tutorials on using LMS-Google Classroom that have developed. The third stage is implementation of LMS-Google Classroom that have developed (IN and ON). The fourth stage is evaluation of implementation result. The result of this PKMS activities are as follows: 1) teachers understand about how to make and develop of LMS-Google Classroom neither learning tool and evaluation tool contents based on digital classroom, 2) teachers are able to use LMS-Google Classroom that have developed; and 3) teachers are able to invite their students for join and learn about learning tool and evaluation tool contents in LMS-Google Classroom enthusiastically.
\end{abstract}

Kata kunci: LMS-Google Classroom, Senior High School Teachers' Competence, Industrial Revolution 4,0 


\section{PENDAHULUAN}

Salah satu dampak dari perkembangan Revolusi Industri 4,0 dalam dunia pendidikan adalah integrase teknologi dalam proses pembelajaran. Penerapan teknologi dalam proses pembelajaran bukan suatu hal yang baru dalam dunia pendidikan. Sejak kurikulum 2013 diberlakukan pada seluruh jenjang Pendidikan formal mulai dari Sekolah Dasar hingga Sekolah Menengah Atas telah dibuat suatu peraturan penerapan teknologi dalam pembelajaran. Namun, integrasi teknologi yang dimaksud pada kenyataan di lapangan hanya dijadikan sebagai media pembelajaran. Seperti penerapan projector atau penggunaan Microsoft power point sebagai media pembelajaran. Kedua teknologi itu saja yang masih sering diterapkan oleh beberapa guru di beberapa sekolah. Namun, seyogianya, penerapan teknologi dalam proses pembelajaran tidak hanya sekedar menjadikannya sebagai media pembelajaran, namun juga mengintegrasikannya ke dalam proses hingga metode pembelajaran. Hal tersebut tertuang jelas dalam Permendikbud No. 65 Tahun 2013 (Kemendikbud, 2013) yang salah satu dipaparkan bahwa pemanfaatan teknologi, informasi dan komunikasi dilakukan dalam proses pembelajaran untuk meningkatkan efisiensi dan efektivitas pembelajaran, dan tidak hanya digunakan hanya sebatas media pembelajaran saja.

Penggunaan teknologi dalam proses pembelajaran diharapkan mampu menjadikan proses pembelajaran tidak terhenti hanya karena waktu pembelajaran berakhir.
Hal itu bermakna bahwa, proses pembelajaran dapat dilakukan bahkan ketika waktu pembelajaran secara formal telah berakhir. Ini yang dinamakan juga sebagai pembelajaran jarak jauh berbasis digital. Kondisi ini yang diharapkan oleh hadirnya era Revolusi Industri 4,0 dalam dunia pendidikan. Salah satu upaya dalam mengintegrasikan teknologi dalam proses pembelajaran hingga menjadikan proses pembelajaran menjadi lebih efisien dan efektif adalah dengan menghadirkan pembelajaran berbasis digital, namun tetap mengadirkan lingkungan pembelajaran tradisional dalam proses pembelajaran di dalam kelas.

Salah satu pembelajaran berbasis digital yang dapat diterapkan sesuai dengan era Revolusi Industri 4,0 adalah Blended Learning. Blended Learning merupakan suatu proses pembelajaran dengan menggabungkan jenis pembelajaran berbasis tatap muka (tradisional), berbasis media pembelajaran dan berbasis digital teknologi. Model blended learning memberikan ruang dan lingkungan pembelajaran yang efisien yang meliputi aspek pembelajaran secara online dan pembelajaran secara tradisional, pembelajaran dengan menggunakan konten media, model pembelajaran yang fleksibel, bersifat mandiri dan memberikan dampak yang nyata terhadap motivasi para peserta didik serta meningkatkan efektivitas proses pembelajaran (Alonso, López, Manrique, \& Viñes, 2005; Bersin, 2004; Garrison \& Vaughan, 2008; Lin, Tseng, \& Chiang, 2017; Thorne, 2003).

Penerapan model blended learning dalam proses pembelajaran 
bukan hal yang baru. Beberapa penelitian menggunakan penerapan model blended learning membuktikan bahwa hasil belajar siswa baik dalam bentuk pengetahuan hingga keterampilan mengalami peningkatan yang lebih baik. Siswa juga merasa termotivasi, antusias dan semangat dalam mengikuti pembelajaran (Borba et al., 2016; Tsai, Lin, \& Lin, 2017).

Pada proses pembelajaran blended learning dibutuhkan suatu Learning Management System (LMS) yang digunakan sebagai bagian dari proses pembelajaran namun dalam fase e-learning. Salah satu produk yang dihadirkan dalam LMS adalah LMS-Google Classroom. Pada kegiatan PKMS ini, tim PKMS Universitas Potensi Utama ingin memberikan pelatihan mengenai pembuatan LMS-Google Classroom hingga implementasinya dalam proses pembelajaran. Alasan pemilihan LMS-Google Classroom sebagai platform digital dalam proses pembelajaran, dikarenakan penerapan sistem pembelajaran Google Classroom mudah dilaksanakan oleh pendidik serta digunakan oleh peserta didik. Google Classroom sebenarnya merupakan LMS berbasis digital yang sistem pembelajarannya sudah siap. Pengguna hanya memerlukan sedikit pengaturan dalam membuat kelas digital dan mengembangkan konten pembelajaran baik berupa konten materi ajar maupun konten evaluasi hasil belajar(Rohman, 2017).

Mitra kegiatan PKMS ini adalah SMA Swasta An-Nizam Medan, Sumatera Utara. Sasaran kegiatan PKMS ini adalah guru-guru semua mata pelajaran di SMA Swasta An-Nizam Medan, Sumatera
Utara sebanyak 25 orang. Berdasarkan hasil wawancara dengan kepala SMA Swasta An-Nizam, yakni Bapak Drs. Sularno, M.P diperoleh informasi bahwa belum pernah diadakan kegiatan pelatihan implementasi LMS-Google Classroom bagi guru-guru di SMA Swasta An-Nizam, Medan, Sumatera Utara. Pemilihan sekolah mitra ini juga disebabkan oleh proses pembelajaran di sekolah mitra sudah menerapkan pembelajaran terintegrasi dengan teknologi, yang diantaranya penggunaan projector, tersedianya $w i-f i$ dan penggunaan Microsoft Power Point dalam memberikan materi pelajaran di dalam kelas. Pengumpulan tugastugas siswa pun sudah menerapkan integrasi teknologi, yakni dengan menggunakan produk Google, yakni Gmail.

Melalui kegiatan PKMS di SMA An-Nizam, diharapkan dapat memberikan pengetahuan, pemahaman hingga keterampilan kepada para guru sehingga dapat membuat dan mengimplementasikan LMS-Google Classroom yang telah dibuat dalam proses pembelajaran pada masing-masing bidang mata pelajaran,

\section{METODE PELAKSANAAN}

Berdasarkan permasalahan di atas, maka solusi yang ditawarkan oleh Tim PKMS Universitas Potensi Utama adalah dengan mengadakan pelatihan implementasi LMS-Google Classroom dalam meningkatkan kompetensi guru SMA, khususnya SMA Swasta An-Nizam di era Revolusi Industri 4,0. Berikut ini diuraikan tahapan kegiatan PKMS di SMA Swasta An-Nizam Medan: 
1. Tahapan pertama adalah tahap persiapan yang meliputi kegiatan survei ke lokasi PKMS, kegiatan wawancara dan observasi pendahuluan pada kepala sekolah dan guru SMA Swasta An-Nizam Medan, penyusunan modul pembuatan LMS-Google Classroom, dan publikasi hasil kegiatan pelatihan.

Kegiatan survei dilakukan dengan tujuan untuk melihat permasalahan yang dimiliki oleh sekolah mitra terkait penggunaan teknologi dalam proses pembelajaran, serta menyesuaikan permasalahan dengan kebutuhan yang diperlukan oleh sekolah mitra. Kegiatan survei yang dilakukan juga diiringi dengan kegiatan observasi pendahuluan dan kegiatan wawancara pada kepala sekolah mitra dan guru sekolah mitra. Hasil dari kegiatan survei, observasi pendahuluan dan wawancara dijadikan tolak ukur untuk mengetahui solusi apa yang diperlukan untuk menyelesaikan masalah serta memenuhi kebutuhan sekolah mitra. Penyusunan modul pelatihan pembuatan LMS-Google Classroom disusun dengan menarik dan lugas

2. Tahapan kedua adalah tahap pelaksanaan pelatihan, yakni pemberian materi pengenalan LMS-Google Classroom secara teoritis.

3. Tahapan ketiga adalah tahapan implementasi LMS-Google Classroom secara IN dan ON. Pada tahapan ketiga ini, tim PKMS juga memberikan angket untuk melihat apakah para guru memahami penjelasan mengenai tahapan pembuatan dan implementasi LMS-Google
Classroom dalam proses pembelajaran.

4. Tahapan keempat adalah tahapan evaluasi hasil dari implementasi LMS-Google Classroom dalam proses pembelajaran. Pada tahapan ini, tim PKMS akan melakukan review dan memberikan saran kepada para guru terhadap hasil pengembangan LMS-Google Classroom yang telah dibuat dan diterapkan.

\section{HASIL DAN PEMBAHASAN}

Upaya kegiatan PKMS Universitas Potensi Utama yang dilakukan berupa kegiatan pelatihan implementasi LMS-Google Classroom untuk meningkatkan kompetensi guru SMA, khususnya SMA Swasta An-Nizam Medan dalam menghadapi era Revolusi Industri 4,0. Kegiatan PKMS ini diadakan dalam empat tahapan, dan dilakukan mulai dari tanggal 9 Maret 2019 hingga 27 April 2019. Kegiatan pelatihan dan implementasi dilakukan mulai dari tanggal 20 April 2019 hingga tanggal 27 April 2019. Semua kegiatan pelatihan yang dilakukan berjalan sesuai dengan jadwal yang telah disusun sebelumnya.

\section{Pelaksanaan Pelatihan}

Uraian pelaksanaan kegiatan pelatihan dijabarkan sebagai berikut:

1. Pembukaan pelatihan berupa sosialisasi kegiatan PKMS yang dilakukan oleh Bapak Kepala SMA Swasta An-Nizam Medan, Bapak Drs. Sularno, M.P.

2. Kegiatan dilanjutkan dengan pemberian piagam penghargaan kepada SMA Swasta An-Nizam selaku Sekolah Mitra yang telah 
bekerja sama dengan sangat baik dalam pelaksanaan kegiatan hibah PKMS-Dikti yang dilakukan oleh Tim Universitas Potensi Utama Medan. Penerimaan piagam penghargaan diwakili oleh Bapak Kepala SMA Swasta An-Nizam Medan, Bapak Drs. Sularno, M.P.

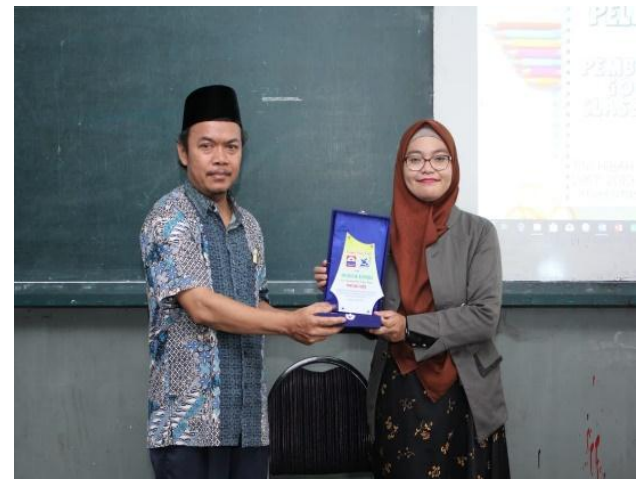

Gambar 1. Pemberian Piagam Penghargaan dari TIM PKMS Universitas Potensi Utama

3. Kegiatan kemudian dilanjutkan dengan pengenalan tim PKMS Universitas Potensi Utama selaku penyelenggara dan pemberi materi pelatihan implementasi LMSGoogle Classroom bagi Guru SMA An-Nizam.

4. Kegiatan pelatihan dilanjutkan dengan pembagian Modul Pelatihan Pembuatan LMSGoogle Classroom yang telah disusun oleh Tim Hibah PKMS Dikti-Universitas Potensi Utama. Berikut tampilan modul pelatihan pembuatan LMS-Google Classroom oleh Tim Hibah PKMS Dikti-Universitas Potensi Utama

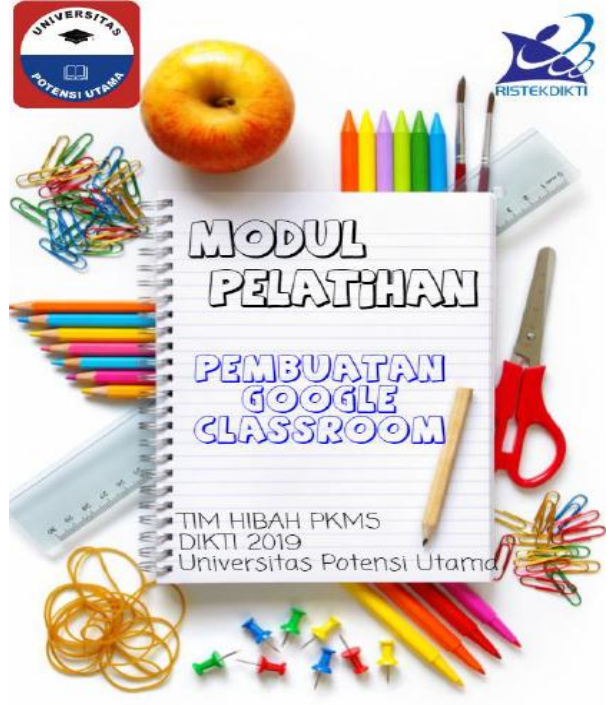

Gambar 2. Tampilan Modul Pelatihan Pembuatan LMS-Google Classroom

5. Kegiatan dilanjutkan dengan pemberian tutorial pembuatan LMSGoogle Classroom secara bertahap. Kegiatan tutorial dilakukan dalam empat kegiatan pelatihan, dimulai dari pembuatan kelas digital menggunakan LMSGoogle Classroom, pembuatan konten bahan ajar jenis LKS berbasis budaya lokal, pengunggahan bahan ajar ke dalam LMS-Google Classroom yang telah dibuat dan pembuatan evaluasi penilaian menggunakan Google Form serta pengunggahannya ke dalam LMSGoogle Classroom. 


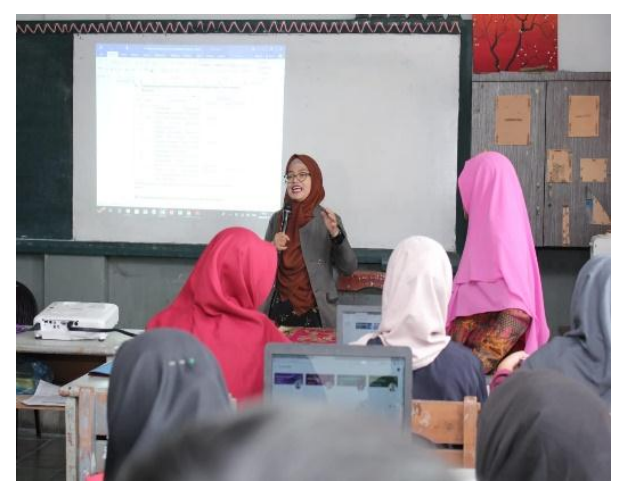

Gambar 3. Tim PKMS Universitas Potensi Utama memberikan tutorial pembuatan LMSGoogle Classroom

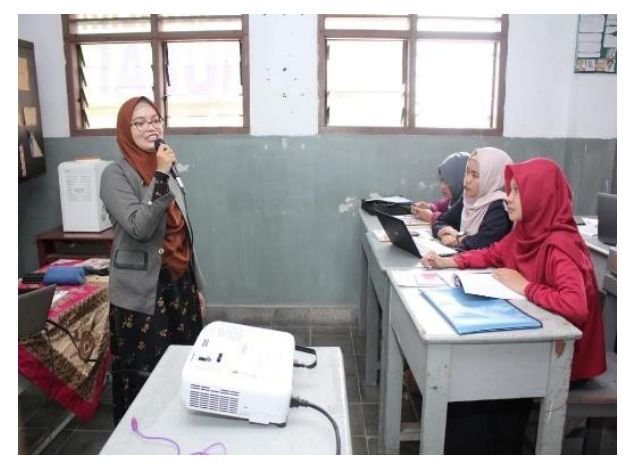

Gambar 4. Tim PKMS Universitas Potensi Utama memberikan penjelasan tentang penerapan LMS-Google Classroom yang pernah dilakukan

6. Setelah peserta pelatihan dapat memahami bagaimana membuat LMS-Google Classroom, membuat konten bahan ajar jenis LKS berbasis budaya lokal, mengunggah konten bahan ajar ke dalam LMS-Google Classroom yang telah dibuat dan membuat evaluasi penilaian menggunakan Google Form serta mengunggahnya ke dalam LMSGoogle Classroom, maka dilanjutkan dengan sesi tanya jawab seputar LMS-Google Classroom dan penggunaannya di dalam kelas serta pemberian angket hasil pelatihan

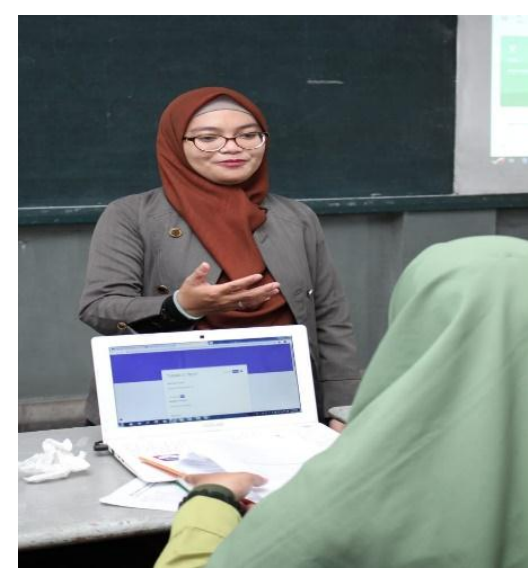

Gambar 5. Sesi Tanya Jawab dengan Para Guru, Peserta Pelatihan

7. Kegiatan kemudian dilanjutkan dengan mengembangkan LMSGoogle Classroom yang telah dibuat secara lebih lengkap baik konten bahan ajar maupun evaluasi penilaian hingga nantinya dapat diimplementasikan dalam proses pembelajaran masingmasing guru bidang studi.

8. Kegiatan diakhiri dengan pemberian motivasi kepada para guru agar dapat meningkatkan pemahaman, pengetahuan hingga keterampilan dalam menggunakan teknologi hingga dapat mengintegrasikannya ke dalam proses pembelajaran.

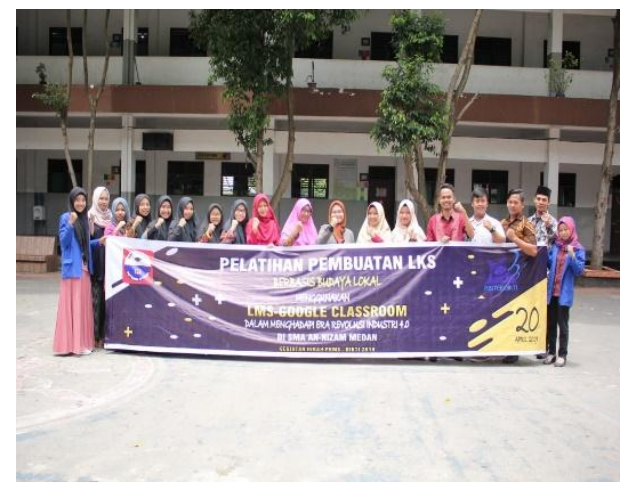

Gambar 6. Foto Bersama Para Guru, Peserta Kegiatan Pelatihan 


\section{Hasil Evaluasi Kegiatan}

Instrumen untuk keefektifan kegiatan PKMS dilakukan dengan menggunakan angket. Angket yang diberikan terdiri dari 20 pernyataan yang terdiri dari pernyataan positif dan pernyataan negatif. Hasil perhitungan instrumen angket yang diberikan dapat dilihat pada gambar di bawah ini:

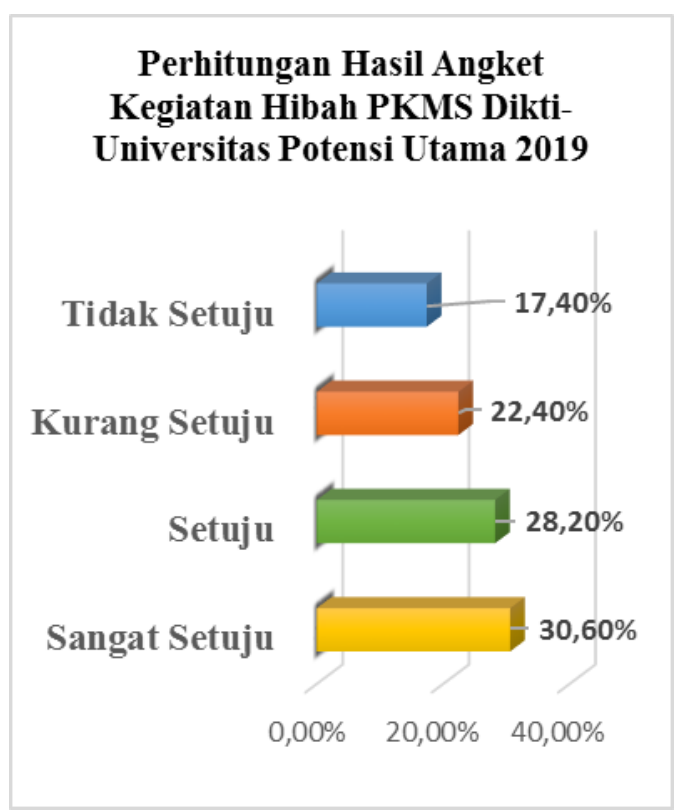

Gambar 7. Hasil Perhitungan Angket

Hasil perhitungan angket kegiatan PKMS pelatihan implementasi LMS-Google Classroom untuk meningkatkan kompetensi guru SMA An-Nizam dalam menghadapi era Revolusi Industri 4,0 diperoleh rata-rata persentase angket berada pada tingkat persentase $84,5 \%$ dan masuk dalam katagori sangat baik). Hal tersebut sesuai dengan tabel katagori perhitungan angket yang dapat dilihat pada tabel 1 di bawah ini:

Tabel 1. Katagori Perhitungan Angket (Arikunto, 2012)

\begin{tabular}{ccc}
\hline No & $\begin{array}{c}\text { Rentang Persentase Hasil } \\
\text { Angket }\end{array}$ & Katagori \\
\hline 1. & $80 \% \leq P \leq 100 \%$ & Sangat Baik \\
2. & $65 \% \leq P \leq 79,99 \%$ & Baik \\
3. & $55 \% \leq P \leq 64,99 \%$ & Cukup \\
4. & $40 \% \leq P \leq 54,99 \%$ & Kurang \\
5. & $0 \% \leq P \leq 39,99 \%$ & Sangat Kurang \\
\hline
\end{tabular}

Berdasarkan hasil perhitungan angket pada gambar 7 di atas juga diperoleh bahwa persentase para guru yang memberikan pernyataan sangat setuju terhadap kegiatan pelatihan sebanyak 30,60\%; persentase para guru yang memberikan pernyataan setuju terhadap kegiatan pelatigan sebanyak $28,20 \%$; persentase para guru yang memberikan pernyataan kurang setuju terhadap kegiatan pelatihan sebanyak 22,40\%; dan persentase para guru yang memberikan pernyataan tidak setuju terhadap kegiatan pelatihan sebanyak $17,40 \%$. Dari persentase angket yang telah diperoleh maka hal ini dapat menunjukkan bahwa kegiatan PKMS ini telah berhasil meningkatkan 
pengetahuan, keterampilan dan motivasi serta antusiasme para guru dalam membuat hingga mengimplementasikan LMS-Google Classroom dalam proses pembelajaran di era Revolusi Industri 4,0.

\section{KESIMPULAN}

Tim PKMS Hibah DiktiUniversitas Potensi Utama telah melaksanakan program pelatihan implementasi LMS-Google Classroom dalam meningkatkan kompetensi Guru SMA Swasta AnNizam dalam menghadapi era Revolusi Industri 4.0 sesuai dengan tahapan yang telah direncanakan. Berdasarkan kegiatan yang telah dilaksanakan, maka dapat disimpulkan sebagai berikut:

1. Kegiatan pelatihan yang telah dilakukan mampu mendorong para guru dalam meningkatkan pengetahuan dan pemahaman mengenai bagaimana proses pembuatan LMS-Google Classroom;

2. Para guru telah mampu membuat LMS-Google Classroom, hingga mengunggah konten bahan ajar dan evaluasi penilaian berbasis Google Form.

3. Para guru telah mampu meningkatkan keterampilannya dalam mengintegrasikan teknologi dalam proses pembelajaran, yang salah satunya adalah implementasi LMS-Google Classroom dalam proses pembelajaran.

\section{UCAPAN TERIMA KASIH}

\begin{tabular}{lllr}
\multicolumn{2}{c}{ Program } & \multicolumn{2}{c}{ kegiatan } \\
disponsori & dan & didanai & oleh \\
Kementerian & Riset & dan Teknologi
\end{tabular}

Pendidikan Tinggi-Direktorat Jenderal Penguatan Riset dan Pengembangan-Hibah Program Kemitraan Masyarakat Stimulus (PKMS) Tahun 2019 sesuai dengan Surat Keputusan No. 8/E/KPT/2019.

\section{REFERENSI}

Alonso, F., López, G., Manrique, D., \& Viñes, J. M. (2005). An instructional model for web-based e-learning education with a blended learning process approach. In British Journal of Educational Technology (Vol. 36). Retrieved from Blackwell Publishing Ltd website:

http://www.fisme.science.uu.nl/pu blicaties/literatuur/2005_modelfor webbasedelearning.pdf

Arikunto. (2012). Dasar-Dasar Evaluasi Pendidikan (2nd ed.). Jakarta: Bumi Aksara.

Bersin, J. (2004). The Blended Learning Book: Best Practices, Proven Methodologies, and Lessons Learned. Retrieved from https://www.researchgate.net/profil e/Nguyen_Trung_Hiep3/post/Can_ anyone_suggest_to_me_any_good _Research_Papers_Articles_etc_on _Blended_Learning/attachment/59 d63e2479197b807799acf7/AS\%3 A422799799001088\%4014778147 35535/download/\%5BJosh_Bersin $\% 5 \mathrm{D} \_$The_Blended

Borba, M. C., Askar, P., Engelbrecht, J., Gadanidis, G., Llinares, S., \& Aguilar, M. S. (2016). Blended learning, e-learning and mobile learning in mathematics education. ZDM, 48(5), 589-610. https://doi.org/10.1007/s11858016-0798-4

Garrison, D. R., \& Vaughan, N. (2008). Blended learning in higher education: Framework, principles, and guidelines. - PsycNET. 
Retrieved from

https://psycnet.apa.org/record/2007 $-16842-000$

Kemendikbud. (2013). Penjamin Mutu Pendidikan Mata Pelajaran Matematika Tingkat SMA Sesuai Kurikulum 2013. Jakarta.

Lin, Y.-W., Tseng, C.-L., \& Chiang, P.J. (2017). The Effect of Blended Learning in Mathematics Course. EURASIA Journal of Mathematics, Science and Technology Education, 13(3), 741-770. https://doi.org/10.12973/eurasia.20 17.00641a

Rohman, F. (2017). Google Classroom: Jadikan Kelas Digital di Genggaman Anda. Bojonegoro: Pustaka Intermedia.

Thorne, K. (2003). Blended Learning: How to Integrate Online and Traditional Learning. Retrieved from www.kogan-page.co.uk

Tsai, T., Lin, J., \& Lin, L. (2017). A Flip Blended Learning Approach for ePUB3 eBook-based Course Design and Implementation. Eurasia Journal of Mathematics, Science and Technology Education, 14(1), 123-144. https://doi.org/10.12973/ejmste/79 629 